\title{
CLINICAL PRIVILIGE DAN TANGGUNG JAWAB DOKTER INTERNSIP DI RUMAH SAKIT
}

\author{
Erwin G. Kristanto
}

\author{
Bagian Kedokteran Forensik \& Medikolegal Fakultas Kedokteran \\ Universitas Sam Ratulangi Manado/RSUP Prof. Dr. R.D Kandou Manado \\ Email: gk_erwin@yahoo.com
}

\begin{abstract}
The internship program is a preregistration professional training program that has to be undertaken by each new graduate medical doctor, educated with a competence-based curriculum. After passing the competence test, the candidates for the internship program, whether civil servants or not, have to pesonally complete their application papers in order to start their professional training programs at the appointed medical health services, eg. a hospital. Since every hospital has different conditions, the medical comittee and the head of the hospital have to prepare the appropriate clinical privileges for the internship doctors. A good clinical appointment will protect the internship doctors while finishing their professional training, and also protect the hospital from any unnecessary risks.
\end{abstract}

Keywords: internship program, clinical privilige.

\begin{abstract}
Abstrak: Program internsip adalah tahap pelatihan keprofesian pra-registrasi yang harus dijalani setiap dokter baru yang dididik dengan kurikulum berbasis kompetensi (KBK). Pasca kelulusan ujian kompetensi dokter Indonesia (UKDI), calon peserta internsip ikatan dinas maupun mandiri wajib mengurus kelengkapan administratif guna melaksanakan tugas keprofesiannya di sarana pelayanan kesehatan, salah satunya rumah sakit. Kondisi rumah sakit yang berbeda satu dengan yang lain, membuat komite medis bersama pimpinan rumah sakit harus membuat kajian clinical privilige yang tepat untuk para dokter internsip. Clinical appointment yang tepat akan melindungi dokter internsip dalam menyelesaikan pelatihan keprofesiannya, dan melindungi rumah sakit dari resiko hukum yang tidak perlu.
\end{abstract}

Kata kunci: Program internsip, clinical privilige.

Program internsip dokter telah dilaksanakan sejak berpuluh tahun lalu di negara lain, namun merupakan program yang baru di Indonesia, yang berlaku untuk dokter baru yang menggunakan program pendidikan kurikulum berbasis kompetensi (KBK) selama pendidikan. Dokter baru yang menyelesaikan program ini akan memperoleh Surat Tanda Selesai Internsip (STSI) yang merupakan prasyarat untuk registrasi kompetensi dokter di Konsil Kedokteran Indonesia (KKI). ${ }^{1}$

Dokter yang melakukan praktik di Indonesia sesuai dengan amanah Undangundang nomor 29 tahun 2004 tentang praktik kedokteran, harus mempunyai Surat Tanda Registrasi (STR). STR merupakan pengakuan pembuat aturan atas kemampuan dokter dalam menjalankan praktik kedokteran di seluruh Indonesia, sekaligus penjamin bahwa masyarakat memperoleh layanan kesehatan dari dokter-dokter yang berkemampuan baik. $^{2}$

Pasien yang memperoleh layanan kesehatan di rumah sakit di Indonesia berhak memperoleh layanan kesehatan yang bermutu sesuai dengan standar profesi dan standar prosedur operasional, termasuk dari dokter internsip. Rumah sakit bertanggung jawab secara hukum terhadap semua keru- 
gian yang ditimbulkan atas kelalaian yang dilakukan oleh tenaga kesehatan di rumah sakit, sehingga rumah sakit memiliki hak untuk turut menentukan clinical privilige dokter intersip yang menggunakan rumah sakit sebagai wahana internsipnya. ${ }^{3}$

\section{PROGRAM INTERNSIP DOKTER INDONESIA}

Program internsip dokter Indonesia adalah tahap pelatihan keprofesian praregistrasi untuk mengasah dan memberi pengalaman dokter baru di sarana pelayanan kesehatan yang telah memenuhi persyaratan yang ditetapkan oleh Komite Internsip Dokter Indonesia Pusat (KIDI Pusat). Program ini telah dilaksanakan mulai tahun 2010 dan awalnya diikuti oleh 12 Fakultas Kedokteran yang telah meluluskan dokter menggunakan KBK yaitu Universitas Indonesia, Universitas Islam Negeri Jakarta, Universitas Hasanudin, Universitas Gajah Mada, Universitas Diponegoro, Universitas Pajajaran, Universitas Tanjungpura, Universitas Andalas, Universitas Airlangga, Universitas Muhammadiyah Jakarta, Universitas Jenderal Sudirman, dan Universitas Brawijaya. Internsip dijalani selama satu tahun atau dapat diperpanjang bila sasaran akhir program belum dicapai. Pelaksanaan internsip wajib sesegera mungkin dilaksanakan, namun penundaan dua tahun setelah lulus masih dimungkinkan. $^{1,4}$

Calon peserta internsip ikatan dinas maupun calon peserta internsip mandiri akan memperoleh pembekalan selama tiga hari oleh KIDI provinsi dan melakukan penandatanganan kontrak internsip. Calon peserta juga akan memperoleh jadwal kegiatan internsip selama 12 bulan, berupa kegiatan di ruang rawat inap, poliklinik, UGD rumah sakit dan Puskesmas. ${ }^{4}$

Dalam mengelola upaya kesehatan perorangan dan upaya kesehatan masyarakat, peserta internsip didampingi oleh seorang dokter pendamping. Kegiatan dokter internsip setiap tiga bulan dilaporkan dalam bentuk buku log (log book) yang ditanda tangani oleh dokter pendamping. Pada akhir masa internsip, dokter pendamping melakukan evaluasi pencapaian program internsip. Peserta yang telah mencapai tujuan program akan memperoleh surat rekomendasi dari dokter pendamping dan pimpinan rumah sakit yang digunakan untuk mengurus Surat Laporan Pelaksanaan Internsip (SLPI) yang akan diterbitkan oleh KIDI provinsi. SLPI inilah yang akan digunakan sebagai rekomendasi penerbitan STSI oleh KIDI Pusat. ${ }^{1}$

\section{CLINICAL PRIVILIGE DAN TANG- GUNG JAWAB HUKUM DOKTER INTERNSIP}

Sebelum menjalankan program internsip, dokter internsip wajib mengurus STR internsip secara kolektif ke Konsil Kedokteran Indonesia. Peserta program internsip juga wajib mengurus SIP Internsip yang diterbitkan oleh Dinas Kesehatan Kabupaten/Kota. Kelalaian pemenuhan syarat ini menjadi tanggung jawab hukum dokter internsip dan sarana pelayanan kesehatan dimana dokter internsip tersebut melakukan praktik kedokterannya. ${ }^{4}$

Pimpinan rumah sakit tempat dokter internsip bekerja, berwenang menetapkan kewenangan klinis (clinical privilige) dokter internsip melalui penugasan klinis (clinical appointment) dengan mengingat kebutuhan program keprofesian dokter tersebut. $^{5} \quad$ Penugasan klinis ini harus ditelaah oleh komite medis mengingat resiko yang dapat timbul dari tindakan keprofesian yang dilakukan oleh dokter internsip. Dokter internsip yang bekerja di rumah sakit berbeda mungkin memperoleh kewenangan dan penugasan klinis yang berbeda pula. Penugasan klinis merupakan peraturan internal rumah sakit yang harus dipatuhi oleh setiap dokter internsip. ${ }^{5}$

Komite medis bersama pimpinan rumah sakit bertugas melindungi kepentingan seluruh tenaga kesehatan di rumah sakit dan pasien yang memperoleh layanan kesehatan di rumah sakit. Penugasan klinis dokter internsip dengan tepat di rumah 
sakit diperlukan untuk mengurangi risiko terhadap rumah sakit dan tenaga kesehatan lain yang terkait dalam pelayana kesehatan pasien. Pembuatan dokumen medikolegal seperti visum et repertum, surat keterangan sakit, penandatanganan dokumen asuransi merupakan contoh kewenangan yang akan memaparkan risiko yang besar pada dokter internsip dan rumah sakit bila ditugaskan pengerjaannya pada dokter internsip. ${ }^{1}$

Sarana pelayanan kesehatan akan terpapar pada risiko tanggung gugat perdata yang lebih besar bila tidak mencermati pengaturan internal terkait dokter internsip. Risiko tanggung renteng gugatan perdata akan amat membebani dokter internsip dan rumah sakit bila dikeluarkan penugasan klinis yang keliru oleh pimpinan rumah sakit. Rumah sakit perlu mencermati bahwa medical staff bylaws bersifat tailor made sehingga materi dan substansi tidak mungkin disamakan antara satu rumah sakit dengan rumah sakit lainnya. Setiap rumah sakit sudah seyogyanya meminta komite medisnya untuk menyusun bylaws terkait pelaksanaan keprofesian dokter internsip di rumah sakit masing-masing. ${ }^{6}$ Adanya perangkat-perangkat ini akan membantu pelaksanaan pelayanan kesehatan di rumah sakit dan menghindarkan tenaga kesehatan serta rumah sakit dari masalah etik, disiplin, dan hukum ke depan. ${ }^{7}$

Dokter internsip mengemban tanggung jawab hukum sebagai tenaga kesehatan. Dokter pendamping tidak bertanggung jawab terhadap tindakan keprofesian yang dilakukan oleh peserta internsip. Sanksi pelanggaran hukum mengacu pada peraturan dan yurisprudensi hukum mengenai tenaga kesehatan. Selama proses hukum, program internsip peserta yang bersangkutan akan ditunda sampai diperoleh putusan berkekuatan hukum tetap. Sanksi pidana dan atau perdata dapat diikuti oleh sanksi administratif sesuai yang ditetapkan dalam peraturan menteri kesehatan dan peraturan konsil kedokteran Indonesia tentang dokter internsip. ${ }^{8,9}$

\section{SIMPULAN}

Dokter internsip merupakan bagian dari masyarakat profesi kedokteran yang harus dilindungi kepentingannya dengan penentuan clinical privilige yang tepat. Analisis penentuan clinical privilige yang tepat dilakukan oleh komite medis tiap rumah sakit sesuai keadaan rumah sakit, dengan semangat pelayanan prima dalam bidang kesehatan.

\section{DAFTAR PUSTAKA}

1. Badan pengembangan dan pemberdayaan sumber daya manusia kesehatan. Departemen Kesehatan RI. Pedoman pelaksanaan internsip dokter Indonesia. Buku 1. Jakarta: Departemen Kesehatan RI, 2009; hal.1-25.

2. Undang-undang nomor 29 tahun 2004 tentang Praktik Kedokteran.

3. Undang-undang nomor 44 tahun 2009 tentang Rumah Sakit. Tambahan Lembaran Negara Republik Indonesia Nomor 5072.

4. Badan pengembangan dan pemberdayaan sumber daya manusia kesehatan. Departemen Kesehatan RI. Pedoman peserta internsip dokter Indonesia. Buku 2. Jakarta: Departemen Kesehatan RI, 2009; hal.1-22.

5. Peraturan Menteri Kesehatan Republik Indonesia Nomor 755/MENKES/PER/ IV/2011 Tentang Penyelenggaraan Komite Medik Di Rumah Sakit.

6. Keputusan menteri kesehatan Republik Indonesia nomor 631/Menkes/SK/IV/2005 tentang peraturan internal staf medis (Medical Staff Bylaws) di rumah sakit.

7. Undang-undang nomor 36 tahun 2009 tentang Kesehatan. Tambahan Lembaran Negara Republik Indonesia Nomor 5063.

8. Peraturan menteri kesehatan nomor 299/Menkes/PER/II/2010 tentang penyelenggaraan program internsip dan penempatan dokter pasca internsip.

9. Peraturan konsil kedokteran Indonesia nomor 1/KKI/Per/I/2010 tentang registrasi dokter program internsip. 